\title{
More than just money: Patterns of disaggregated welfare expenditure in the enlarged Europe
}

\author{
Kati Kuitto* \\ Department of Political Science, University of Greifswald, Greifswald, \\ Germany
}

\begin{abstract}
Summary This article demonstrates the potential of the disaggregated expenditure approach in comparative welfare state analysis by applying it for comparing patterns of welfare spending across 28 European countries. An initial factor analysis shows that welfare states differ primarily along their emphasis either on cash transfers for the elderly or on social services and cash transfers for the working-age population. European welfare states cluster along these two spending dimensions in a way that to a great extent coincides with the well-known delineation of welfare regimes based on institutional characteristics. Furthermore, the results attest to the emergence of a variety of welfare arrangements in the post-communist region, yet with a general orientation toward a Bismarckian or conservative model. The results of this analysis demonstrate that disaggregated welfare expenditure measures retain considerable importance in elucidating the realities of contemporary welfare policy.
\end{abstract}

Keywords cluster analysis, disaggregated social expenditure, welfare regimes

Comparing national patterns of welfare policies and classifying divergent types of welfare states constitutes an important field of comparative welfare state research (for an overview, see, for example, Abrahamson, 2000; Arts and Gelissen, 2002; Bambra, 2007; for the genesis of the regime analysis, see Castles and Obinger, 2008). Typologybuilding is thereby not just an intellectual endeavour or an end in itself, but an important analytical means to an end. Typologies serve as a tool for cognitive simplification. In Richard Titmuss' words: 'The purpose of model-building is not to admire the architecture of the building, but to help us see some order in all the disorder and confusion of facts, systems and choices' (Titmuss, 1974: 30). Welfare state classifications and typologies offer a meaningful point of origin for theory-building and causal analysis, when not only single programmes or institutions, but also the entirety of welfare state arrangements is the focus of the research interest. This is often the case in macro-quantitative comparisons.

Classification systems have long been dominated by indicators of welfare institutions and social rights. In contrast to simple measures of social expenditure, the superiority of institution and rights-based typologies has been repeatedly stressed in the past. Yet the lack of comparable and conceptually substantiated time series data on welfare policies and institutions is still an Achilles' heel in comparative analysis (Clasen and Siegel, 2007). ${ }^{1}$ As a consequence, cross-country comparisons of welfare policy patterns and their causes and effects have either been limited to countries for which more sophisticated data like welfare state generosity is available, (that is, the Organisation of Economic Co-operation and Development (OECD) countries)

\footnotetext{
"Author to whom correspondence should be sent: Kati Kuitto, Department of Political Science, University of Greifswald, Baderstrasse 6/7, D-17489 Greifswald, Germany. [email: kuitto@uni-greifswald.de]
} 
or aggregate social expenditure is still taken as a proxy measure for welfare stateness especially in analyses with pooled designs. The latter is especially unsatisfying, since total social expenditure reveals barely anything of the contents of welfare policies and is often misleadingly interpreted as a measure of welfare generosity.

As increasingly more attention is paid to the dynamics of welfare arrangements on the one hand, and to the configuration of welfare state arrangements in developing and middle-income countries on the other, the question of feasible measures for welfare policies and the demand for appropriate and comparable data gains added importance. One way of addressing this problem consists of refining the conception and utility of expenditure measures by relying on disaggregated social expenditure data and thus on the functional differentiation of welfare spending. These kinds of data illuminate the contents of welfare policy effort, namely, which programmes and purposes governments emphasize in the realm of welfare. Two sources, the Social Expenditure Database (SOCX) by the OECD and the European System of Integrated Social Protection Statistics (ESSPROS) by the Eurostat, now provide scholars with annual, time series data for a large number of countries.

This article argues that the potential of disaggregated expenditure data is far from being fully exhausted in comparative welfare policy analysis. Building upon earlier approaches (see for example Castles, 2004, 2008; Flora, 1986; Kautto, 2002; Klau, 1985; Saunders and Jensen, 2008; Tepe and Vanhuysse, 2010), I demonstrate that disaggregated expenditure data is well suited for comparative endeavours and, even though telling less about the quality or effectiveness of welfare policies for the recipients, it reveals important parameters of welfare policy arrangements especially from the public policy perspective. This article seeks to extend the disaggregated expenditure approach for comparative analysis of welfare policy patterns by addressing the following question: Do disaggregated welfare spending patterns reveal significant cross-country variation among European welfare states in line with a theoretically meaningful distinction between welfare regimes? In order to test this empirically, I take on Castles' (2008) framework of four distinct spending categories. While Castles' approach was primarily descriptive, derived from observing the distinct spending patterns among Western OECD countries, I apply a more robust method by utilizing factor and cluster analysis for 28 European countries and use the ESSPROS data. This approach integrates the Central and Eastern European (CEE) new member states of the European Union (EU) in the quantitative comparative analysis of welfare policy patterns - an attempt that has gained little methodologically substantiated attention thus far. Applying the newly available disaggregated data will facilitate exploring which ways the emerging patterns of welfare policy arrangements in these countries correspond to those prevalent in Western Europe. In contrast to most previous analyses, I also account for social needs pressure factors potentially affecting welfare spending levels by adjusting the data with adequate weights. The results show that European countries cluster in a theoretically meaningful way along their functional welfare spending. These clusters coincide to a high extent with different regimes or worlds of welfare.

The study is structured as follows: the next section discusses advantages, possibilities and limits of disaggregated expenditure approaches and introduces three contemporary classifications of welfare states based on their functional spending structure. The third section outlines the data and method used in this study and discusses the data treatment for adjusting welfare expenditure for needs pressures. In the fourth section, the dimensionality of welfare spending is first depicted through a factor analysis before testing how 28 European welfare states cluster with respect to distinct categories of welfare policy expenditure. The characteristics of the clusters revealed by the analysis are subsequently discussed. The final section concludes by discussing the advantages and caveats of this approach for future research.

\section{Disaggregated social expenditure as a measure for welfare policy patterns}

\section{Advantages and limits of expenditure approaches in welfare state comparisons}

As has been noted repeatedly by scholars of comparative welfare state research, total social expenditure gives little information about the substantive content or generosity of welfare policies. Esping-Andersen 
correctly argues that 'by scoring welfare states on spending, we assume that all spending counts equally' and that 'expenditures are epiphenomenal to the theoretical substance of welfare states' (Esping-Andersen, 1990: 19). With this critique, expenditure measures faded from the research agenda, although total social expenditure is still often - and frequently rather blindly - used as an indicator for the extent of welfare stateness in many comparative macroquantitative studies, simply due to the availability of data. ${ }^{2}$ For comparative purposes, the validity of the indicators at hand inevitably depends on the question one aims to answer and the assumptions one makes a priori. Therefore, how expenditure measures are operationalized for analytical purposes is of key importance (Castles, 2004; Siegel, 2007). In general, total social expenditure is considered a valid measure of the overall welfare effort (De Deken and Kittel, 2007; Siegel, 2007). Especially in times of economic hardship, allocation of governmental budgets and the costs of social provision become particularly contentious in political debates. Consequently, the actual emphasis on social matters as measured by social expenditure illuminates many politically relevant aspects of welfare policy (Siegel, 2007).

Examining the structure of social expenditure, particularly through a more sensitive disaggregated analysis, sheds more light on the contents of the welfare effort and thus the political salience of different welfare policy programmes. Using disaggregated data offers several advantages (Castles, 2004; Siegel, 2007). First, it improves aggregate measures and makes them more theoretically informed and comparable over time and across countries. Second, using disaggregated data offers insights into the asymmetries between different domains of welfare policy and makes it possible to account for volatility in the structure of welfare policies over time. Moreover, looking at disaggregated data allows for distinguishing 'welfare state structures in terms of the kinds of social provision they offer' (Castles, 2004: 48). This way, it is possible to develop empirically based typologies. Finally, the data availability for a great number of countries on an annual basis is an indisputable advantage that enables more systematic research designs and time series analyses and thus contributes better to the needs of scholarly work in comparative welfare state research.
Looking at disaggregated and functionally distinct spending data does of course not alter the fact that expenditure figures do not reveal much about the distributional logic of welfare policies or the social rights in a given welfare state (Siegel, 2007). Institutional measures remain the only alternative when such dimensions of welfare policy settings are the focus of research. Furthermore, gross expenditure levels do not consider possible tax effects that may lead to considerable variance in net expenditure depending on the taxation or non-taxation of cash benefits (cf. Adema and Ladaique, 2005).

\section{Worlds of welfare spending?}

While several studies draw on disaggregated or decomposite spending data in analysing welfare policies (for example Alestalo and Uusitalo, 1992; Flora, 1986; Saunders and Klau, 1985), classification attempts on the basis of spending figures are less widespread. At the most general level, public expenditure on social purposes can be distinguished by spending on cash benefits or transfers (for example, pensions or unemployment benefits) and on benefits in kind or services (for example, childcare facilities or services for disabled). Starke et al. argue that this division is not a trivial one, but instead that the role of transfers and services in the national 'welfare mix' is one of the defining characteristics of welfare state regimes (Starke et al., 2008: 984). Spending on transfers corresponds roughly to the decommodification dimension in EspingAndersen's terms and spending on services to the defamilization dimension. Accordingly, welfare states differ based on the degree to which they emphasize one of these dimensions (for example, Jensen, 2008; Kautto, 2002; Korpi and Palme, 1998). In corporatist-conservative welfare states, spending on transfers outbalance spending on services, often because caring for the elderly or children is primarily seen as the responsibility of the family. In Scandinavian welfare states, the share of service spending is high since care functions are taken over by the state, but generous benefit levels and universal eligibility criteria also lead to high levels of spending on cash transfers (Esping-Andersen, 1999; Kautto, 2002). Within the liberal welfare cluster, only modest levels of cash benefits compliment a rather important service provision (Castles, 1993). 
In a cluster analysis including 15 EU member states in 1990 and 1997, Kautto finds support for the existence of three distinct country clusters when clustering these countries according to the relative weight of their service effort. A first 'service effort group' consists of primarily the Nordic countries, while a second 'transfer approach group' consists of Belgium, the Netherlands, Austria and Italy. A third group is characterized by both low service and low transfer effort and includes Ireland and the Mediterranean countries (Kautto, 2002: 62).

The distinctiveness of transfer and service spending is also supported by a clustering approach for 18 OECD countries in 2001 by Jensen (2008). Four clusters, which to a large part coincide with the three welfare regimes identified by Esping-Andersen, emerge when distinguishing between expenditure on transfers and social services. Jensen further argues that an emphasis on healthcare services follows a distinct logic compared with other social service expenditure because social services reflect differing degrees of ideological saliency in different regimes, while healthcare is a more ideologically non-salient issue (Jensen, 2008: 159; see also Anttonen et al., 2003).

Francis G. Castles further differentiates between four functionally specific spending categories (2008). ${ }^{3}$ The following four categories, which are based on the present classification system of the OECD SOCX data, build the basis for Castles' analysis (Castles, 2008: 48):

- Age-related cash benefits (old-age and survivors' cash benefits)

- Working-age benefits (income support payments in respect of incapacity, unemployment, families and social assistance plus spending on active labour market policies)

- Healthcare services (benefits in kind)

- Other service expenditure (all social services other than health)

These four categories illuminate the intentions of welfare spending better than the simple division in transfers and services. They likewise provide more possibilities for linking the data with conceptual contents. For example, the category of working-age cash benefits accounts for all kinds of risks (old and new) that citizens face in the course of their working lives and thus corresponds more specifically to the idea of decommodification than cash transfers in general. Pensions and survivors' benefits to a certain extent follow a different logic and are based on previous savings and contributions - especially in the corporatist-oriented countries.

Through examining levels of spending as a percentage of gross domestic product (GDP) in 2003, Castles not only shows that considerable cross-national variation between the four categories occurs, but also that the 23 Western OECD countries included in the analysis differ in their spending profiles and form clusters or, in his own earlier terms, 'families of nations'. Like the clusters detected in Jensen's analysis, these families correspond to Esping-Andersen's welfare regimes. According to Castles, different areas of expenditure are not significantly correlated. Together with the descriptive analysis of the spending figures, this underlines the argument that not only do some countries spend more than others, but also that countries differ considerably in their spending priorities and that these priorities seem independent from levels of social spending. Therefore, the disaggregated social expenditure approach 'has the potential to provide us with new information about the nature, the causes and the consequences of welfare state variation' (Castles, 2008: 51-2).

Despite the strikingly lucid argumentation about the grouping of countries, the analysis performed by Castles (2008) is less substantiated in methodological terms since it leans purely on a description of the spending patterns. This study ties in with the disaggregated expenditure approach proposed by Castles but employs a more sophisticated statistical method based on factor and cluster analysis. The approach is applied for 28 European countries in order to reassess whether disaggregated spending profiles coincide with different established and emerging welfare regimes. Besides the Western European EU member states, the post-socialist CEE countries are included in the analysis as well.

In line with the results of Castles' study, the Western European welfare states should cluster along their spending patterns in a way that has been postulated by the studies mentioned above. However, the spending patterns in the CEE countries are hypothetically more open. Although some comparative work has already been done, identifying emerging patterns of CEE welfare regimes is still tentative, largely resulting from the lack of quantitative data on welfare institutions and other policy measures for these countries (see, among others, 
Cerami and Vanhuysse (2009), Inglot (2008) and Szikra and Tomka (2009); for patterns of public policy in more general, see Castles and Obinger, 2008). In general, social expenditure in the CEE countries is on average lower than in the Western European countries, yet considerable cross-country variation occurs (Jahn and Kuitto, 2010). Previous studies have revealed that the mostly Bismarckian pre-socialist institutional setting of the CEE welfare states influenced the configuration of the postsocialist welfare policies (Cerami and Vanhuysse, 2009; Inglot, 2008; Szikra and Tomka, 2009). Accordingly, the CEE countries should exhibit similarities with corporatist Western European counterparts. Another hypothetical direction of the welfare arrangements in the CEE countries would be a liberal model, providing only basic social security in case of loss of income due to neoliberal influences and financial emergencies in the course of the transition period. For reasons of austerity, it is less likely that the universalistic features and extensive state services provided by socialist governments would have persisted in the post-socialist period.

\section{Variables, data and method}

\section{Variables and data}

The following empirical analysis applies a modification of Castles' approach for 28 European countries in 2005-7. ${ }^{4}$ The ESSPROS data allows including the non-OECD countries of the EU in the analysis. Castles' concept, which was based on SOCX data, is therefore modified to conform to the spending categories offered by the ESSPROS data. In contrast to Castles, who includes spending on active labour market policies (ALMP) into the dimension of working-age benefits, this study focuses on welfare policies in a narrower sense and therefore excludes ALMP spending. Activation policies in general are certainly gaining more and more importance in many countries and their impact on the living conditions of the working-age population has been pointed out by Powell and Barrientos (2004), Serrano Pascual and Magnusson (2007), and Castles (2008) among others. Yet, if one would like to analyse patterns of governmental effort for social policies in a broader sense, one should consider not only ALMP, but also other policy fields such as education (Jensen, 2008; Hudson and Kühner, 2010). In the narrower sense applied in this study, welfare policies include basic social security programmes and social services, which are essential for cushioning diverse social risks in individuals' lives.

Given these adjustments, the following variables in the four functional spending categories reported in Table 1 were included in this analysis, measured as percentage of GDP.

Utilizing the ESSPROS data affects the comparability of the data and results of this study with the

Table 1 Categories of welfare policy spending used in this study

\begin{tabular}{|c|c|c|c|c|}
\hline & \multicolumn{2}{|c|}{ Cash benefits } & \multicolumn{2}{|c|}{ Benefits in kind } \\
\hline & $\begin{array}{l}\text { Age-related cash } \\
\text { expenditure }\end{array}$ & $\begin{array}{l}\text { Working-age income } \\
\text { replacing expenditure }\end{array}$ & $\begin{array}{l}\text { Healthcare } \\
\text { services } \\
\text { expenditure }\end{array}$ & $\begin{array}{l}\text { Social services } \\
\text { expenditure }\end{array}$ \\
\hline $\begin{array}{l}\text { ESSPROS categories } \\
\text { used in this study }\end{array}$ & $\begin{array}{l}\text { - Old-age cash } \\
\text { benefits } \\
\text { - Survivors' cash } \\
\text { benefits }\end{array}$ & $\begin{array}{l}\text { - Unemployment cash } \\
\text { benefits } \\
\text { - Sickness cash benefits } \\
\text { - Disability cash benefits } \\
\text { - Family cash benefits }\end{array}$ & $\begin{array}{l}\text { - Healthcare } \\
\text { benefits in } \\
\text { kind }\end{array}$ & $\begin{array}{l}\text { - Old-age benefits } \\
\text { in kind } \\
\text { - Family benefits in } \\
\text { kind } \\
\text { - Disability benefits } \\
\text { in kind } \\
\text { - Survivors' benefits } \\
\text { in kind } \\
\text { - Unemployment } \\
\text { benefits in kind } \\
\text { - Social exclusion } \\
\text { benefits in kind }\end{array}$ \\
\hline
\end{tabular}


previous studies discussed above, since they are based on the SOCX data. As has been shown by De Deken and Kittel (2007), the ESSPROS and SOCX data differ considerably in some regards. For example, the OECD has taken a different approach to that of Eurostat in defining what actually counts as public spending. While in the ESSPROS data, spending is defined as 'public' if the decision power lies with the government, in the SOCX data spending is only considered to be 'public' when it is carried into execution by governmental sector agents. In other words, the ESSPROS data also includes mandatory schemes in public expenditure. Therefore, spending figures are in most cases systematically higher than the respective figures by the SOCX data (De Deken and Kittel, 2007: 74). In addition, spending in some categories counts differently. Although the functional categories accounted for in this study and in Castles' analysis are nearly identical in both data sources, the correlations are far from being perfect when accounting for all commonly available years and countries for which both SOCX and ESSPROS data are available. ${ }^{5}$

\section{Adjusting the data for demographic and needs pressures}

Given that expenditure on social benefits is highly dependent on the population in need, this needs to be accounted for when analysing expenditure data (Clayton and Pontusson, 1998; Huber and Stephens, 2001; Kangas and Palme, 2007; Saunders and Klau, 1985; Siegel, 2007). If aiming to identify patterns of welfare spending in a cross-country setting, with the underlying assumption that these patterns indicate the welfare policy priorities of governments, then variation caused by factors automatically affecting the levels of social expenditure should be eliminated. For example, the number of unemployed persons leads to a higher ratio of unemployment cash benefits in proportion to GDP independent of political decisions or any changes in the legislation concerning unemployment benefits. As great cross-county variation exists with regard to the population in need, leaving this unconsidered would distort the comparison. ${ }^{6}$ In this analysis, I account for cyclical and structural needs resulting from the size of population entitled to different benefits through weighting the disaggregated expenditure categories by respective structural and demographic variables.
Although it is not possible to determine the exact numbers of (potential) recipients, I use proxy variables that come closest to the needs pressures. The two most common needs pressure factors are the unemployment rate and the proportion of elderly population (the percentage of population over 65 years old of the total population). Consequently, the unemployment cash benefits and benefits in kind are weighted by the unemployment rate. The old-age cash benefits and benefits in kind are weighted by the ratio of population aged over 65 years old. ${ }^{7}$

In case of family and sickness benefits, it is more difficult to measure the needs pressure in a proper way. Family or childcare allowances make up the greatest part of family cash benefits and so I follow the suggestion by Kangas and Palme and weight the expenditure on family cash benefits by the proportion of persons aged 16 years or younger (Kangas and Palme, 2007: 110). ${ }^{8}$ Family benefits in kind consist mainly of child daycare costs and therefore expenditure on family benefits in kind is weighted by the proportion of children under school age (below 7 years of age). ${ }^{9}$ In case of sickness benefits, again in line with the suggestion by Kangas and Palme, life expectancy is taken as a proxy for the overall health status of the population. The basic assumption is that the adult population is healthier in countries where life expectancy is higher. Therefore, there should be less sickleave days among the working-age population. Although this measure is only a very rough approximation and also prone to counterfactual argumentation, I weight sickness cash benefits by the reversed life expectancy in absence of more suitable alternative data. ${ }^{10}$ For healthcare benefits in kind, I perform inverse weighting: when life expectancy is high, higher expenses for the healthcare systems occur simply due to the fact that a greater proportion of elderly persons in the total population is likely to raise the need for medical care. Therefore, sickness benefits in kind are weighted by life expectancy.

For all other fields of benefits, no weighting was made due to a lack of adequate data on persons in need for time series and across the countries. Weighting some of the benefit dimensions by pressure factors and leaving others unweighted certainly leads to somewhat biased data, but since these unweighted categories sum up only to 4.5 percent of GDP on average (or 17.6 percent of total social spending), the bias should be less serious than when leaving the major benefit categories unweighted. 
The adjustment procedure results in values which are on average 14.3 percent lower than the unweighted values in the case of age-related cash benefits, 5.8 percent in the case of working-age cash benefits, 22.2 percent in the case of healthcare services, 9.1 percent in the case of social services and finally 13.3 percent of total social spending.

\section{Method}

In a first step, the dimensionality of welfare spending is depicted through an explorative factor analysis allowing for interdependence of the factors (principal component analysis with Oblimin rotation) and n components using the means for 2005-7 of the four spending categories. The factor analysis facilitates discovering potential latent dimensions behind the observed data but at the same time is also a necessary step for dealing with problems of multicollinearity in the subsequent cluster analysis. The four spending categories are correlated partly to a substantially high degree in the sample of countries in this study. In particular, age-related cash expenditure correlates with healthcare services $(r=0.579 * *)$ and working-age cash expenditure correlates with both healthcare expenditure $(0.517 * *)$ and social service expenditure $(0.682 * *)$. Due to these correlation patterns, the spending categories should not be included in the cluster analysis simultaneously because highly correlated variables can implicitly overweight some of the variables in the clustering procedure, thus distorting the results. Using factor scores in the clustering procedure is one established way to deal with this problem (Everitt et al., 2001).

In the second step, in order to explore whether and how European countries group along their spending profiles, I apply an agglomerative hierarchical clustering procedure (hierarchical cluster analysis, HCA) using the squared Euclidian distance as a distance measure and the Ward method as clustering algorithm. For classifying countries along theoretically and empirically distinctive features, cluster analysis is the method of first choice (Bambra, 2007; Gough, 2001; Kangas, 1994). After an extensive period of under-representation in comparative welfare state research, cluster analysis has gained momentum in attempts to classify welfare states or to identify welfare regimes (Bambra, 2007; Gough, 2001; Jensen, 2008; Kautto, 2002; Powell and Barrientos, 2004; Obinger and Wagschal, 2001;
Saint-Arnaud and Bernard, 2003). The goal of cluster analysis is to determine clusters of objects that display small within-cluster variation relative to between-cluster variation. The specific clustering method utilized in this analysis determines cluster membership on the basis of the total sum of squared deviations from the mean of cluster and has proven to perform well in allocating cases 'correctly' to clusters (Bergs, 1981; Everitt et al., 2001). Therefore, it has become a standard for many social scientific clustering approaches to solve classification problems (for example, Castles and Obinger, 2008; Jensen, 2008). The robustness of the clusters is further tested by the means of alternative clustering methods.

\section{Findings}

\section{Dimensionality of welfare spending}

As described earlier, the spending categories correlate to some degree. An explorative factor analysis allows for further inspection of underlying patterns of welfare policy spending behind the spending figures. If the assumption that welfare policy spending in cash benefits is distinct from spending on benefits in kind is to hold true, as has been suggested, among others, by Kautto (2002), then the agerelated cash spending and working-age cash spending should load on one dimension and the spending on healthcare services and other social services on another dimension. Yet this is not the case. The analysis resulted in two distinct dimensions accounting for 85.3 percent of the total variation: the first consisting of working-age cash spending and social services spending; the second consisting of old-age cash and healthcare in kind spending (Table 2). Healthcare service spending loads on the first factor as well, but the factor loading is much higher on the second factor. The first factor is characterized by the highest loading for social service spending and the second by age-related spending.

The factor analysis was also run with pooled data from 1995-7 and only for the Western European countries in order to see whether the two dimensions also hold true when including time series or only the mature welfare states. Given the relatively small number of cases, jack-knifing, that is, excluding each case at a time, was additionally applied in order to control for possible effects of single cases 
Table 2 Results of the factor analysis with the four categories of welfare spending (\% of GDP, means 2005-7)

Components

\begin{tabular}{lccc} 
& Factor 1 & Factor 2 & Uniqueness \\
\cline { 2 - 4 } & 0.958 & & 0.102 \\
Social service expenditure & 0.854 & & 0.178 \\
Working-age cash expenditure & & 0.971 & 0.186 \\
Age-related cash expenditure & 0.348 & 0.735 & 0.123 \\
Healthcare service expenditure & 55.65 & 29.63 & \\
Total variance explained $(\%)$ &
\end{tabular}

Notes: Extraction method: principal component analysis. Rotation method: Oblimin with Kaiser normalization. Values lower than 0.30 are suppressed.

Data source: Eurostat ESSPROS

on the results. In all cases, very similar results occur. I also conducted a factor analysis with the single components of the different spending categories in order to see whether the a priori grouping of welfare spending into theoretically based categories dominates the results. The results indicate that old-age cash spending, survivor's cash spending and sickness benefits in kind make up the three strongest loadings for the first component. Family benefits in kind, old-age benefits in kind and sickness cash benefits are the dominant three variables in the second component. Unemployment cash benefit spending is more ambiguous, loading moderately in both dimensions. ${ }^{11}$

Altogether, the results give little support for the distinctiveness of welfare policy spending simply in cash and services spending as the two dominant dimensions of welfare spending choices. Instead, the spending priorities in these European countries seem to be distinguished by income replacement after working-life on the one hand, and in investment in social services and working-age income maintenance on the other. In other words, some welfare states emphasize old-age benefits over other fields of welfare provision - a type of benefit which is often based on contributions during working life and typical for conservative-corporatist welfare states. Other welfare states, where the second spending dimension dominates, feature a social investment strategy in services and working-age benefits. The addressees represent broader layers of the society in terms of age, gender and employment status and this kind of welfare spending is particularly conducive to decommodification and defamilization. Healthcare service spending seems to be distinct from the other spending categories to a certain extent although it is more pronounced in countries scoring high on the first dimension. This supports the non-salience of the healthcare viewpoint in welfare policy priority setting (Jensen, 2008).

\section{Clusters of welfare spending patterns}

Given the dimensionality of welfare spending, how do the European welfare states cluster along the two spending dimensions? In a first step of the cluster analysis, only the Western European countries were included in the hierarchical cluster analysis in order to examine how the spending patterns of the mature welfare states fit into the established regime categories. The factor scores resulting from the factor analysis above are entered in the cluster analysis as clustering variables as previously mentioned. The results presented in Figure 1 strongly support the idea of distinct worlds of welfare spending, showing that four clusters emerge that largely correspond to the established regimes. Yet some deviations also occur. First, Austria, Belgium, Germany, France and the Netherlands form one cluster, but contrary to many other categorization attempts, the UK and Switzerland also join this cluster, which could be characterized as the conservative Continental European cluster. ${ }^{12}$ Second, the Scandinavian countries form a distinct Nordic cluster which is first formed by Denmark and Sweden and then joined by Iceland, Norway and Finland. Third, Greece, Portugal and Italy group together, thus forming a Southern European cluster. A fourth cluster, which seems less coherent in theoretical terms, which I therefore call a Mixed cluster, consists of Ireland, 
Rescaled Distance Cluster Combine

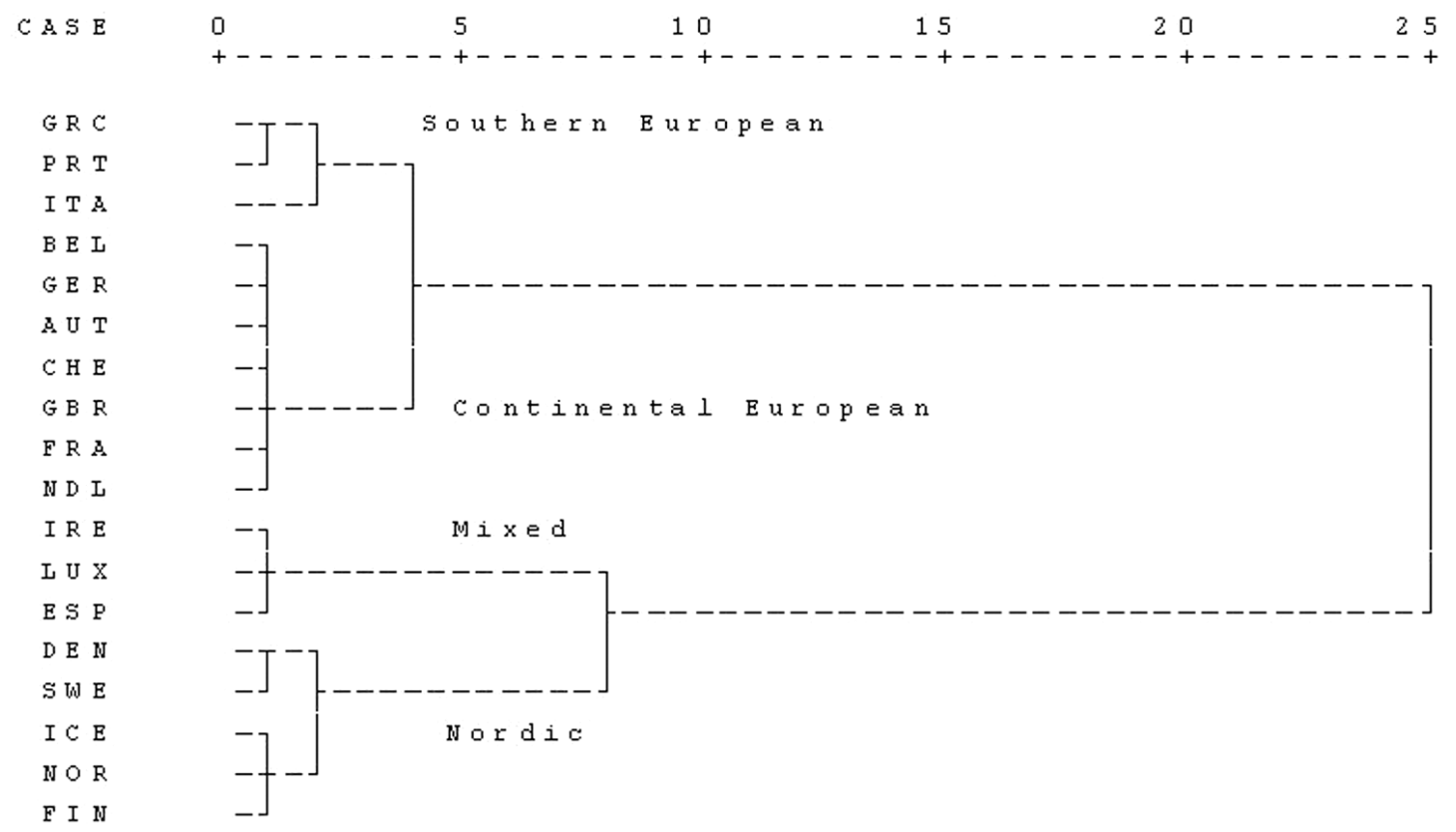

Figure 1 Clusters of welfare spending in Western European countries, 2005-7. Results of an HCA using the Ward method and square Euclidian distance.

Data source: Eurostat ESSPROS.

Luxembourg and Spain. Contrary to most of the previous categorization attempts, clustering along welfare spending patterns neither disposes the UK and Ireland to building a distinctive liberal or English-speaking family, nor groups them in one and the same cluster. $^{13}$ The main dividing line runs between the Continental and Southern European clusters on the one hand and the Nordic and the Mixed clusters on the other. As previously stated among others by Ferrera (1996), the Mediterranean countries seem to share some characteristics with the conservative Continental countries. From some viewpoints, they are not considered 'an intrinsically distinct model, but rather a less developed continental one' (Berghman, 1997: 125) or 'a discount edition of the continental model' (Abrahamson, 1995).

In a second step, the ten post-communist countries were incorporated in the cluster analysis. The results of the hierarchical cluster analysis presented in Figure 2 support the insight that instead of forming a unique Eastern European welfare regime, welfare policy patterns in the CEE have developed in different directions (see also Cerami, 2006; Inglot, 2008; Szikra and Tomka, 2009). On the one hand, the Baltic countries, along with Slovakia, Bulgaria, Romania and Poland, form a distinctive cluster of their own, which might be described as the developing Eastern European cluster. On the other hand, the rest of the CEE countries join one of the predominantly Western European clusters. While Slovenia shares features of the Southern European cluster, the Czech Republic and Hungary group together with Spain, Luxemburg and Ireland in the Mixed cluster.

\section{Robustness of the clusters}

The robustness of the clusters produced by the hierarchical cluster analysis was first tested by utilizing another agglomerative hierarchical clustering method - the complete linkage method. For this method, the cluster criterion is based on maximum distance between a pair of objects residing in different 
Rescaled Distance Cluster Combine

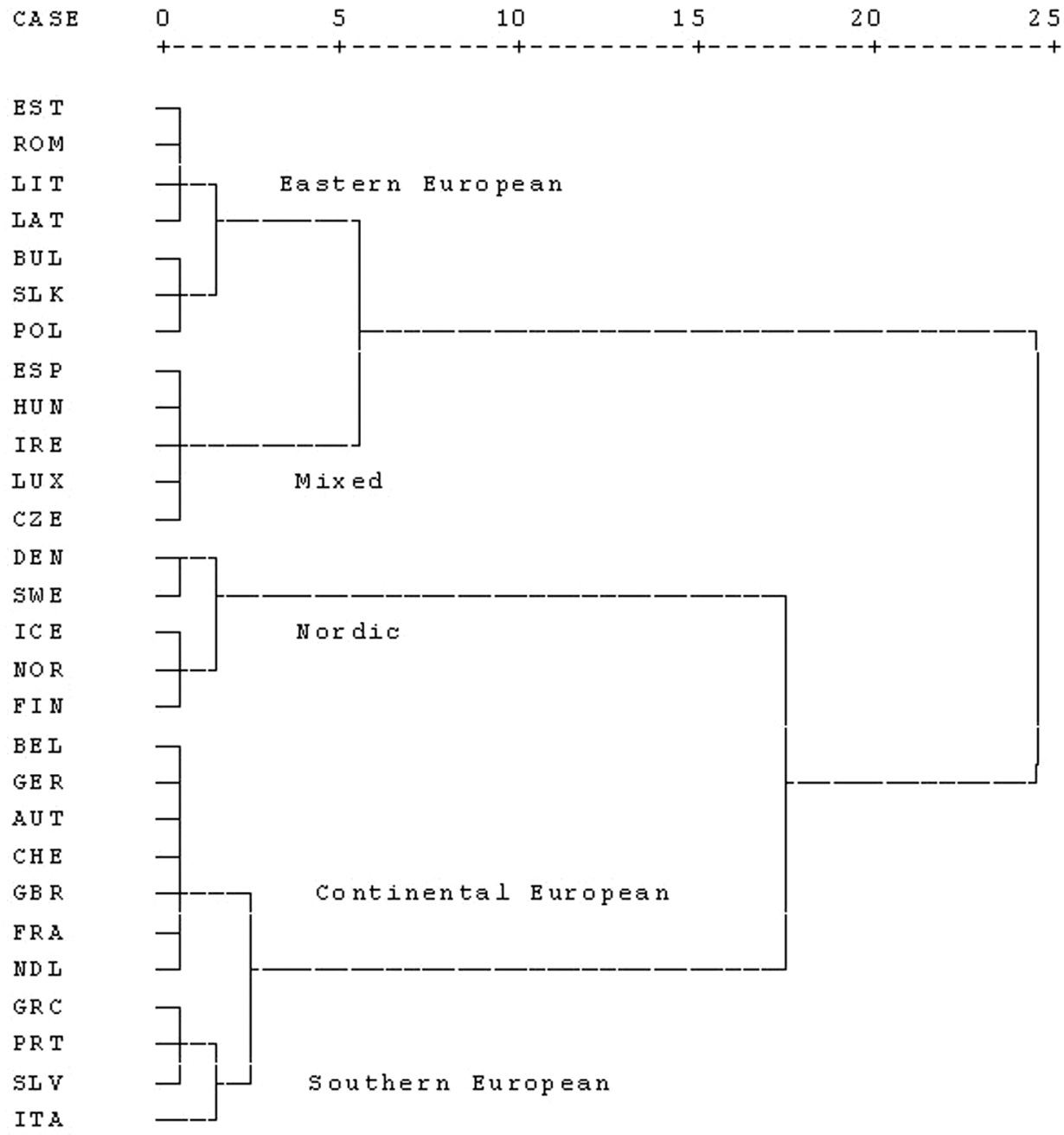

Figure 2 Clusters of welfare spending in Western European countries, 2005-7. Results of an HCA using the Ward method and square Euclidian distance.

Data source: Eurostat ESSPROS.

clusters. This method is not as sensitive for outliers than the Ward's method, but tends to build compact and equally sized clusters with equal diameters (Everitt et al., 2001). While the clusters iterated by the hierarchical cluster analysis using Ward's method remain fairly stable, a few countries now join another cluster. Italy changes from the Southern European to the Continental cluster, but is still clearly distinct from the other members of this group. The Netherlands now joins the Nordic group and links most closely to Finland. The Southern European cluster now is also closer to the Eastern European and the Mixed ones, the Nordic and the Continental clusters are independent in the initial splitting. 
Second, the hierarchical cluster analysis was run with the original four spending categories instead of the factor scores for checking whether the selection of the variables has an impact on the extracted clusters. Basically, the same clusters appear, but some of the countries now join other clusters. The Netherlands is part of the Nordic cluster while Iceland, Norway and Ireland form their own cluster which affiliates to the Mixed cluster at a later stage. In addition, the UK is now part of the Southern European cluster. As previously mentioned however, this procedure might be sensitive to distortions caused by multicollinearity, which is why using the factor scores was chosen in the first place.

Third, it was tested how countries cluster when setting the number of clusters a priori by running the partitioning $k$-means clustering procedure (KCA). The rationale behind this is that we first make theoretical assumptions about the expected number of clusters and then see how our observations group empirically into the defined number of clusters. The number of clusters was set at three (corresponding to the original three worlds of Esping-Andersen (1990)), four (the former plus a Southern cluster) and five (the former plus an Eastern European cluster or the five 'families of nations' identified by Castles (2008)). The threecluster solution produces one cluster identical to the Nordic one in the hierarchical cluster analysis, a second cluster consisting of the Continental and the Southern European countries and a third cluster which combines the Eastern European and the Mixed groups. In the four-cluster solution, the developing welfare states of Eastern European countries now separate into their own cluster; and finally the five-cluster solution reveals an identical pattern as the hierarchical cluster analysis.

Finally, given the relatively small number of cases, the cluster analysis was also run with the jack-knife method in order to test whether the results are driven by single cases. This is not the case. Summing up the results of these robustness tests, we can conclude that the patterns found in the hierarchical cluster analysis are robust.

\section{Characteristics of the welfare spending patterns across the country clusters}

What are, then, the constitutive patterns of welfare spending of the five country clusters? The original and the needs-adjusted spending figures for the means of 2005-7, in distinct welfare policy categories, are presented in Table 3 for all 28 European countries. At the most general level, the clusters are distinguished by their overall level of total social spending as a percentage of GDP. The average total spending is highest in the group of conservative Continental European countries, followed by the Nordic countries. The variation in the Southern cluster is lowest in the whole sample and highest in the Nordic cluster. This is especially due to the very high total spending level in Sweden - the highest among the European countries - and the moderate spending level in Iceland. The countries in the Southern European cluster also show rather high overall spending levels, with Poland as an exception in this regard. The Eastern European cluster is in turn characterized by very modest overall social spending proportionate to their GDP. Welfare policy in these post-communist countries thus has far less priority in governmental budgeting as in the other European countries. The Mixed group is situated between the Eastern and the Southern European country clusters.

The Continental cluster is furthermore characterized by high cash spending on age-related benefits. While all other categories also show rather high spending levels, spending on social services is far less pronounced in terms of proportional governmental spending. This is in line with the traditional focus of the conservative-corporatists or Bismarckian welfare states on contribution-based social security benefits and only 'essential' welfare services including healthcare (for example, Palier, 2010). The UK is to a certain extent an outlier in this group, not only because its spending on working-age cash benefits is considerably lower than the other countries of this group, but also because it groups with these countries in the first place. Originating from the universalistic idea of welfare by Beveridge, the welfare system in the UK should actually be in strict contrast to the conservative-corporatist welfare states of this cluster and their Bismarckian tradition. Yet the contemporary British welfare state represents a hybrid model that hardly corresponds to any of the idealtypical welfare regimes (Cochrane and Clarke, 1997: 73). It is often considered coming closest to the liberal regime following the original attribution by Esping-Andersen, although the UK features the characteristics of the liberal regime on the 
decommodification and stratification dimension only to a modest degree (Esping-Andersen, 1990). The liberal character is expressed among other things in the low generosity of income replacement through cash benefits, thus at least partly explaining the below-average spending on working-age cash benefits. The British system furthermore contains attributes of the conservative regime type in that social security benefits dominate over public welfare services in importance (Schmid, 2010: 187).

The Southern European cluster shares the high cash spending on age-related issues and the relative importance of healthcare services spending with the Continental cluster. Working-age cash spending and social services in turn are far less pronounced in these countries. Healthcare services make up about the same relative importance in relation to total social spending as in the Continental cluster. This cluster can be seen as a more rudimentary and family-oriented variant of the conservative welfare state (see also Esping-Andersen, 1999; Ferrera, 1996).

The countries of the Nordic cluster show considerably higher levels of spending for social services, on average well over twice as high as those of the nearest cluster - the Continental. The emphasis on welfare services such as childcare and old-age care facilities is a well-known feature of the social-democratic welfare model and the supply of social care services outside the family sphere accounts decisively in the defamilizing character of the Nordic welfare states (Bambra, 2007; Esping-Andersen, 1990, 1999; Kautto, 2002; Korpi, 2000; Jensen, 2008; Palme et al., 2009). But high working-age cash expenditure is likewise characteristic for the Nordic cluster, reflecting the generous benefit levels, universal eligibility criteria and high coverage of social security benefits typical for these countries. One of the benefit categories accounting for the relatively high cash benefits in the working phase of life is child benefits and cash benefits for parental leave, with Nordic countries offering the most generous benefits in this category. The Nordic welfare cluster is thus characterized by welfare spending priorities resulting both in a high level of defamilizing and decommodifying measures. Age-related spending is proportionally lower than spending on cash benefits for the working-age population. Iceland is clearly a deviant case in this cluster, its expenditure on old- and working-age benefits are considerably lower than in the rest of the Nordic countries.

The Eastern European cluster shows low overall levels of spending in all categories and the Baltic countries, Bulgaria, Romania, Slovakia and Poland can therefore be titled as developing or minimalistic welfare states. Social services have barely any comparative significance, with the percentage of spending in this category, in most cases, not even exceeding 1 percent of GDP. Poland differs to some extent from the other countries of this cluster, its spending in old-age benefits is considerably higher, while working-age cash benefits is somewhat higher than the average of the cluster. In general, when looking at the proportions of different spending categories in relation to total social spending, this country cluster strongly exhibits the proportions prevalent in the conservative Continental cluster. The hypothesis that the conservative or Bismarckian model reflects the characteristics of the emerging welfare state types in the post-communist countries thus seems to hold true (Cerami, 2006; Inglot, 2008). It remains to be seen whether social matters will gain importance within governmental spending strategies in the longer run, if these countries' GDPs converge with the established welfare states.

Finally, the countries in the Mixed cluster also show a pattern similar to the Continental cluster, with the age-related cash spending being the most important category, followed by working-age cash benefits, healthcare services and finally social services. As this cluster is rather heterogeneous, it does not seem appropriate to characterize the countries included in this cluster as a unique type of welfare state. These countries might still be developing in different directions.

Summing up, the clusters that resulted from the hierarchical cluster analysis are characterized by very distinct patterns of welfare spending and varying emphases on functionally different domains of social protection and welfare provision. By and large, these clusters are in accordance with the ones identified by Castles (2008), although single countries group differently. Given the analogies in spending profiles of the Continental, the Southern, and the Eastern clusters identified in this study, and the clearly deviating spending pattern of the Nordic cluster, the main dividing line in welfare effort and underlying welfare policy arrangements in Europe seems to be constituted by whether welfare policy focuses on the provision of social services and cash 
Table 3 Types of welfare state expenditure, original and adjusted values (in \% of GDP, means 2005-7)

\begin{tabular}{|c|c|c|c|c|c|c|c|c|c|c|}
\hline & \multicolumn{2}{|c|}{$\begin{array}{l}\text { Age-related } \\
\text { cash benefits }\end{array}$} & \multicolumn{2}{|c|}{$\begin{array}{l}\text { Working-age } \\
\text { cash benefits }\end{array}$} & \multicolumn{2}{|c|}{$\begin{array}{c}\text { Healthcare } \\
\text { services }\end{array}$} & \multicolumn{2}{|c|}{$\begin{array}{c}\text { Social } \\
\text { services }\end{array}$} & \multicolumn{2}{|c|}{$\begin{array}{l}\text { Total social } \\
\text { expenditure }\end{array}$} \\
\hline & orig. & adj. & orig. & adj. & orig. & adj. & orig. & adj. & orig. & adj. \\
\hline \multicolumn{11}{|c|}{ Cluster 1: Continental European } \\
\hline Austria & 13.0 & 11.2 & 6.5 & 6.1 & 6.0 & 4.8 & 2.1 & 2.0 & 27.6 & 24.0 \\
\hline Belgium & 12.7 & 11.0 & 7.9 & 7.3 & 6.4 & 5.1 & 1.3 & 1.3 & 28.3 & 24.7 \\
\hline France & 12.7 & 11.0 & 6.3 & 5.7 & 8.0 & 6.5 & 2.2 & 2.1 & 29.3 & 25.3 \\
\hline Germany & 11.9 & 10.1 & 6.9 & 6.4 & 6.7 & 5.4 & 2.1 & 2.1 & 27.6 & 23.9 \\
\hline The Netherlands & 10.1 & 8.9 & 6.8 & 6.7 & 6.7 & 5.3 & 3.0 & 2.8 & 26.6 & 23.7 \\
\hline UK & 10.8 & 9.2 & 4.3 & 4.0 & 7.4 & 5.8 & 2.9 & 2.8 & 25.4 & 21.9 \\
\hline Switzerland & 12.6 & 10.8 & 5.9 & 5.7 & 5.9 & 4.8 & 1.7 & 1.7 & 26.2 & 22.9 \\
\hline Mean & 12.0 & 10.3 & 6.4 & 6.0 & 6.7 & 5.4 & 2.2 & 2.1 & 27.3 & 23.8 \\
\hline$S T D$ & 1.0 & 0.9 & 1.0 & 1.0 & 0.7 & 0.6 & 0.6 & 0.5 & 1.2 & 1.1 \\
\hline \multicolumn{11}{|c|}{ Cluster 2: Southern European } \\
\hline Greece & 12.2 & 10.3 & 3.0 & 2.8 & 6.2 & 4.9 & 2.5 & 2.4 & 23.9 & 20.4 \\
\hline Portugal & 11.2 & 9.6 & 4.8 & 4.6 & 6.5 & 5.1 & 1.1 & 1.0 & 23.6 & 20.3 \\
\hline Slovenia & 9.8 & 8.5 & 4.9 & 4.7 & 6.0 & 4.7 & 1.1 & 1.0 & 21.8 & 18.9 \\
\hline Italy & 15.4 & 12.8 & 3.1 & 3.0 & 6.3 & 5.1 & 0.7 & 0.7 & 25.5 & 21.6 \\
\hline Mean & 12.2 & 10.3 & 4.0 & 3.8 & 6.3 & 5.0 & 1.4 & 1.3 & 23.7 & 20.3 \\
\hline$S T D$ & 2.1 & 1.6 & 0.9 & 0.9 & 0.2 & 0.2 & 0.7 & 0.7 & 1.3 & 1.0 \\
\hline \multicolumn{11}{|l|}{ Cluster 3: Nordic } \\
\hline Denmark & 9.0 & 7.7 & 8.1 & 7.7 & 5.2 & 4.1 & 6.3 & 5.9 & 28.7 & 25.3 \\
\hline Sweden & 9.6 & 8.1 & 7.4 & 7.1 & 6.1 & 5.0 & 6.8 & 6.3 & 30.0 & 26.4 \\
\hline Finland & 8.6 & 7.4 & 7.3 & 6.9 & 5.4 & 4.3 & 4.0 & 3.7 & 25.3 & 22.2 \\
\hline Iceland & 4.8 & 4.3 & 5.5 & 5.2 & 6.3 & 5.1 & 4.6 & 4.3 & 21.2 & 18.9 \\
\hline Norway & 5.3 & 4.6 & 8.0 & 7.7 & 5.0 & 4.0 & 4.4 & 4.0 & 22.6 & 20.3 \\
\hline Mean & 7.5 & 6.4 & 7.2 & 6.9 & 5.6 & 4.5 & 5.2 & 4.8 & 25.6 & 22.6 \\
\hline$S T D$ & 2.0 & 1.8 & 0.9 & 1.0 & 0.5 & 0.5 & 1.1 & 1.2 & 3.4 & 3.2 \\
\hline \multicolumn{11}{|c|}{ Cluster 4: Eastern European } \\
\hline Bulgaria & 7.7 & 6.5 & 2.9 & 2.7 & 3.7 & 2.7 & 0.6 & 0.6 & 14.9 & 12.5 \\
\hline Estonia & 5.3 & 4.5 & 3.2 & 3.0 & 3.3 & 2.4 & 0.4 & 0.4 & 12.3 & 10.3 \\
\hline Latvia & 5.4 & 4.5 & 2.6 & 2.5 & 2.7 & 1.9 & 0.9 & 0.8 & 11.5 & 9.8 \\
\hline Lithuania & 5.9 & 5.1 & 2.6 & 2.6 & 3.5 & 2.5 & 1.1 & 1.0 & 13.1 & 11.2 \\
\hline Romania & 5.8 & 5.0 & 2.8 & 2.6 & 3.1 & 2.3 & 0.9 & 0.9 & 12.6 & 10.7 \\
\hline Poland & 11.2 & 10.0 & 4.0 & 3.8 & 3.2 & 2.4 & 0.3 & 0.3 & 18.7 & 16.5 \\
\hline Slovakia & 6.4 & 5.8 & 3.9 & 3.6 & 4.4 & 3.3 & 1.0 & 0.9 & 15.7 & 13.5 \\
\hline Mean & 6.8 & 5.9 & 3.1 & 3.0 & 3.4 & 2.5 & 0.7 & 0.7 & 14.1 & 12.1 \\
\hline STD & 1.9 & 1.8 & 0.5 & 0.5 & 0.5 & 0.4 & 0.3 & 0.3 & 2.3 & 2.2 \\
\hline \multicolumn{11}{|c|}{ Cluster 5: Mixed/unclassified } \\
\hline Czech Republic & 7.6 & 6.6 & 4.5 & 4.3 & 5.3 & 4.0 & 0.9 & 0.8 & 18.2 & 15.8 \\
\hline Hungary & 8.8 & 7.6 & 5.2 & 4.9 & 5.5 & 4.0 & 2.3 & 2.2 & 21.8 & 18.6 \\
\hline Ireland & 4.3 & 3.9 & 5.2 & 4.7 & 6.3 & 5.0 & 1.3 & 1.2 & 17.2 & 14.9 \\
\hline Luxemburg & 7.4 & 6.6 & 6.6 & 6.0 & 4.3 & 3.4 & 1.8 & 1.7 & 20.1 & 17.7 \\
\hline Spain & 8.1 & 7.0 & 5.2 & 5.0 & 5.3 & 4.3 & 1.9 & 1.8 & 20.4 & 18.0 \\
\hline Mean & 7.2 & 6.3 & 5.3 & 5.0 & 5.3 & 4.1 & 1.6 & 1.5 & 19.5 & 17.0 \\
\hline STD & 1.5 & 1.4 & 0.7 & 0.6 & 0.6 & 0.6 & 0.5 & 0.5 & 1.6 & 1.6 \\
\hline Mean all & 9.1 & 7.8 & 5.2 & 4.9 & 5.4 & 4.2 & 2.2 & 2.0 & 21.8 & 18.9 \\
\hline STD all & 3.0 & 2.5 & 1.7 & 1.7 & 1.4 & 1.2 & 1.7 & 1.6 & 5.6 & 5.0 \\
\hline Min & 4.3 & 3.9 & 2.6 & 2.5 & 2.7 & 1.9 & 0.3 & 0.3 & 11.5 & 9.8 \\
\hline $\operatorname{Max}$ & 15.4 & 12.8 & 8.1 & 7.7 & 8.0 & 6.5 & 6.8 & 6.3 & 30.0 & 26.4 \\
\hline
\end{tabular}

Data source: Eurostat ESSPROS. 
transfers for the working-age population or on social security via cash transfers especially for people in retirement.

Although the dynamics of welfare spending patterns is not in the focus of this study, it is finally worth mentioning that especially the Scandinavian and the Continental cluster remain very stable over time since the mid 1990s, the period for which disaggregated data for these countries is available. There is more fluctuation in the Mixed and the Southern cluster. The Southern cluster only formed in 2003, at least in the constellation with which it has been identified in this study. Before that, Greece and Portugal group together with the Mixed cluster while Slovenia and Italy are more clearly connected to the Continental group. Ireland resembles the Baltic countries in the late 1990s and early 2000s, possibly reflecting the common liberal character of these welfare states. Iceland represents another interesting case, moving from the liberal and Mixed groups to the Scandinavian family by the turn of the millennium. The higher dynamics in the Mixed, Southern and of course Eastern European clusters seem to support the developing character of the welfare states in these clusters.

\section{Conclusion}

This article has made an attempt to refine the disaggregated welfare expenditure approach by using it to identify patterns of welfare spending in 28 European countries. The analysis was based on the approach introduced by Castles (2008), but amendments were made both in conceptual terms and regarding the treatment of the data. A way of accounting for needs pressure factors, which inevitably affect the comparability of the levels of social spending across countries, was applied by weighting the data.

The results initially demonstrate that, contrary to the conclusions of some earlier studies, welfare policy effort does not seem to be bifurcated in cash transfers and services in the sense that these would build the main dimensions around which welfare regimes cluster. Instead, welfare states in Europe differ primarily with regard to the extent to which they invest either on income maintenance in old-age or in social services and cash transfers to working-age population. The spending priorities of different welfare state types, which constitute the two dimensions of welfare spending, thus reflect a divergent political response to the different social risks during distinct periods of the life cycle.

Second, divergent welfare spending patterns indeed can be identified along these functionally different dimensions of welfare expenditure. The mature European welfare states cluster in a way which coincides largely with the regimes or worlds of welfare identified in previous studies. The welfare policy patterns of the CEE countries attest to the emergence of a variety of welfare arrangements in the post-communist region. Common to all CEE countries, though, is a general orientation in the direction of Bismarckian or Continental model and the overall lower spending ratios proportionate to GDP compared with most Western European countries.

These results suggest that theoretically important distinctions between different types of welfare states can indeed be empirically drawn from disaggregated spending data. Welfare regimes do not only differ in their institutional settings rooted in the conception of social rights, but also in their budgetary emphasis on different welfare policy targets. The linkage of spending patterns and institutional features therefore poses an interesting theoretical and empirical puzzle, demonstrating that expenditure figures have more to offer in comparative welfare policy analysis than is often presumed. The disaggregated spending approach is attractive and fruitful for quantitative comparative analysis of welfare states and public policies also because data is available, thus providing options to expand the scope of analysis for countries neglected in comparative settings so far. Disaggregated data further facilitates causal analysis in pooled cross-sectional time-series settings and the analysis of spatial dynamics in welfare policy development.

As with all measures, one must carefully define and disclose the theoretical and analytical limits when using disaggregated expenditure data. Yet the disaggregated expenditure approach and the available data provide comparative scholars with an appropriate tool for analysing welfare policy patterns and their change as both dependent and independent variables, thus being better that its reputation. The data opens up a great variety of potential research directions. The next steps in advancing this approach should include a more in-depth linking of spending patterns with the theoretical substance of the different institutional 
settings of the worlds of welfare, as well as an analysis of programme- and function-specific developments. The determinants and consequences of welfare spending patterns also invite further analysis. While the causal mechanisms behind the formation of welfare regimes in general presumably also account for explaining the spending patterns per se, testing how domestic political, socio-demographical and international factors shape welfare spending for different social needs and clientele certainly adds to our understanding of welfare policy dynamics. Analysing the causes of the emerging welfare spending patterns in the post-communist countries provides a further research avenue arising from the empirical classification of the CEE countries. For example, have similar political power constellations during the 1990s brought about the Bismarckian type welfare states in the CEE as was the case earlier with the continental European countries? Likewise, the development of the spending patterns and consequent clusters calls for in-depth analysis, especially in the face of the international demographic and budgetary pressures. Finally, considering the interest of many comparative approaches to include both mature and developing welfare states in the analysis, finding ways to synthesize SOCX and ESSPROS data is one of the challenges quantitative welfare state scholars should address in the future.

\section{Notes}

I would like to thank Olli Kangas, Detlef Jahn, Lyle Scruggs, Nils Düpont, Douglas Voigt and the participants of the stream 'Comparative Methodology. Neglected Issues and Innovative Methods: Identifying Best Practice' at the 8th ESPAnet Conference 2010, as well as the two anonymous referees and the editor of this journal for their extremely helpful comments on earlier versions of this paper. The research on which this paper is partly based is funded by the German Research Foundation DFG, Research project 'Welfare Policies in the Enlarged Europe' (JA 638/12-1, http://welfare.uni-greifswald.de).

1. The data provided in the Comparative Welfare Entitlements Dataset (CWED) by Lyle Scruggs (18 OECD countries, 1960/1970-2002, available at http://www.sp.uconn.edu/ scruggs/wp.htm) and in the Social Citizenship Indicator Program (SCIP) by Walter Korpi and Joakim Palme (18 countries, 19302000 in mainly 5 -year sequences, available at https:// dspace.it.su.se/dspace/handle/10102/7), are valuable exceptions in this regard. Nevertheless, the temporal and spatial scope of these datasets limits the analytical focus that can be addressed.
2. Data are especially scarce when longer time series, countries outside the OECD world and/or the entity of welfare policy arrangements are the focus of the analysis.

3. For an earlier, slightly different approach, see Castles (2002, 2004).

4. I use means of these 3 years, 2007 being the last year for which data are currently available. While a simple cross-sectional analysis is always sensitive for outliers or coincidental values, using means for more than just 1 year diminishes the random character of cross-sectional analysis and also the risk measurement errors.

5. Age-related cash $0.791 * *$, working-age cash $0.947 * *$, healthcare $0.705 * *$ and other services $0.969 *$. For this comparison, spending on active labour market policies (ALMP) was not included in the working-age cash expenditure, as was done in the original categories by Castles (2008).

6. For example, in 2006, the rate of unemployed of total labour force varied between 3.0 percent (Iceland) and 13.9 percent (Poland). The ratio of population aged 65 yearsand over of the total population varied between 11.0 percent (Ireland) and 19.8 percent (Italy) and the ratio of children under school age of the total population between 6.1 percent (Bulgaria) and 9.9 percent (Ireland) (data from Eurostat).

7. Statutory retirement age varies across countries, 65 years being the most common official retirement age for (male) employees. The de facto average exit age was 61.2 years in the EU25 in 2007 (European Commission, 2009).

8. The age limits for childcare allowance vary greatly, but in most countries, cash benefits are paid at least until the age of 16 years. The measure used here has therefore to be regarded as a very rough approximation.

9. Again, school entry age varies across Europe, but in most countries children enter primary school at latest at the age of 7 years and are thereafter not in need of daycare facilities anymore. Of course, family benefits are not restricted to daycare facilities, but these make out the greatest financial share of family benefits in kind.

10. For calculating the weighting factor, the maximum life expectancy in the sample ( 82.16 years, Switzerland in 2008 ) was set at 100 and all other values were then indexed along this benchmark.

11. In addition, the robustness of the factor solution was tested by applying an orthogonal rotation method (Varimax). The results are almost identical with the oblique rotated solution (Oblimin) reported in Table 2 . Given that factors are rarely truly orthogonal in the real world and given the correlations between some of the spending categories included in this analysis, the oblique rotation is the first choice. But since the oblique rotation produces factors that are orthogonal, that is, uncorrelated, we can be sure that the factor results are not an artifact of the choice of rotation. At the same time, the factor scores accessing the cluster analysis are not correlated to a significant degree (cf. Kline, 1994; Pett et al., 2003).

12. In order to avoid misleading terminology and keeping in mind the explorative character of this study, I abstain from using more content-specific attributes 
for the clusters, but instead use geographic terms (see also Castles and Obinger, 2008; Ferrera, 1996). To some extent, though, these geographic labels are of course connoted with the common characteristics underlying the regimes or worlds of welfare, be it of a cultural, societal or political nature. In some cases, these labels do not do justice to single countries in the literally geographic sense (for example, Great Britain in the 'Continental' cluster).

13. Since most of the 'liberal' or 'Anglo-Saxon' countries (the USA, Canada, Australia, New Zealand) to which Great Britain and Ireland usually are attached are excluded from this analysis, the formation of such a cluster is unlikely per definition, though.

\section{References}

Abrahamson, P. (1995) 'Europe: A Challenge to the Scandinavian Model of Welfare?', in B. Amoroso and J. Jespersen (eds) Welfare Society in Transition. Annals 1994. Roskilde: Roskilde University.

Abrahamson, P. (2000) 'The Welfare Modelling Business', in N. Manning and I. Shaw (eds) New Risks, New Welfare: Signposts for Social Policy. Malden, MA: Blackwell Publishers.

Adema, W. and Ladaique, M. (2005) Net Social Expenditure, 2005 edition. More Comprehensive Measures of Social Support. OECD social, employment, and migration working papers, no. 29. Paris: OECD.

Alestalo, M. and Uusitalo, H. (1992) 'Social Expenditure: A Decompositional Approach', in J.E. Kolberg (ed.) The Study of Welfare State Regimes. Armonk/London: M.E. Sharpe, Inc.

Anttonen, A., Sipilä, J. and Baldock, J. (2003) 'Patterns of Social Care in Five Industrial Societies: Explaining Diversity', in A. Anttonen, J. Baldock and J. Sipilä (eds) The Young, the Old and the State: Social Care Systems in Five Industrial Nations. Cheltenham: Edward Elgar.

Arts, W. and Gelissen, J. (2002) 'Three Worlds of Welfare or More? A State-of-the Art Report', Journal of European Social Policy 12(2): 137-58.

Bambra, C. (2007) 'Defamilisation and Welfare State Regimes: A Cluster Analysis', in International Journal of Social Welfare 16(4): 326-38.

Berghman, J. (1997) 'Can the Idea of Benchmarking be Applied to Social Protection?', Bulletin Luxembourgeois des Questions Sociales 4: 119-29.

Bergs, S. (1981) Optimalität bei Clusteranalysen. Dissertation, University of Münster.

Castles, F.G. (ed.) (1993) Families of Nations: Patterns of Public Policy in Western Democracies. Aldershot: Ashgate/Dartmouth.

Castles, F.G. (2002) 'Developing New Measures of Welfare State Change and Reform', European Journal of Political Research 41(5): 613-41.

Castles, F.G. (2004) The Future of the Welfare State: Crisis Myths and Crisis Realities. Oxford: Oxford University Press.

Castles, F.G. (2008) 'What Welfare States Do: A Disaggregated Expenditure Approach', Journal of Social Policy 38(1): 45-62.
Castles, F.G. and Obinger, H. (2008) 'Worlds, Families, Regimes: Country Clusters in European and OECD Area Public Policy', West European Politics 31(1/2): 321-44.

Cerami, A. (2006) Social Policy in Central and Eastern Europe: The Emergence of a New European Welfare Regime. Berlin: LIT Verlag.

Cerami, A. and Vanhuysse, P. (2009) 'Introduction: Social Policy Pathways, Twenty Years after the Fall of the Berlin Wall', in A. Cerami and P. Vanhuysse (eds) PostCommunist Welfare Pathways: Theorizing Social Policy Transformations in Central and Eastern Europe. Basingstoke: Palgrave Macmillan.

Clasen, J. and Siegel, N.A. (2007) 'Comparative Welfare State Analysis and the "Dependent Variable Problem", in J. Clasen and N.A. Siegel (eds) Investigating Welfare State Change: The 'Dependent Variable Problem' in Comparative Analysis. Cheltenham/Northampton: Edward Elgar.

Clayton, R. and Pontusson, J. (1998) 'Welfare State Retrenchment Revisited: Entitlement Cuts, Public Sector Restructuring, and Inegalitarian Trends in Advanced Capitalist Societies', World Politics 51(1): 67-98.

Cochrane, A. and Clarke, J. (eds) (1997) Comparing Welfare States: Britain in International Context. London: Sage Publications.

De Deken, J. and Kittel, B. (2007) 'Social Expenditure Under Scrutiny: The Problems of Using Aggregate Spending Data for Assessing Welfare State Dynamics', in J. Clasen and N.A. Siegel (eds) Investigating Welfare State Change: The 'Dependent Variable Problem' in Comparative Analysis. Cheltenham/Northampton: Edward Elgar.

Esping-Andersen, G. (1990) The Three Worlds of Welfare Capitalism. Princeton, NJ: Princeton University Press.

Esping-Andersen, G. (1999) Social Foundations of Postindustrial Economies. Oxford: Oxford University Press.

European Commission (2009) The 2009 Ageing Report: Economic and Budgetary Projections for the EU-27 Member States (2008-2060). European Economy 2/2009. Luxembourg: European Communities.

Eurostat (2010) European System of Integrated Social Protection Statistics (ESSPROS). Available at http://epp. eurostat.ec.europa.eu/portal/page/portal/living_conditions_and_social_protection/data/database (accessed 5 October 2010).

Everitt, B.S., Landau, S. and Leese, M. (2001) Cluster Analysis, 4th edition. London: Arnold.

Ferrera, M. (1996) 'The "Southern Model" of Welfare in Social Europe', Journal of European Social Policy 6(1): 17-37.

Flora, P. (ed.) (1986) Growth to Limits: The Western European Welfare States Since World War II. Volumes I-II. Berlin: Walter de Gruyter.

Gough, I. (2001) 'Social Assistance Regimes', Journal of European Social Policy 11(2): 165-70.

Huber, E. and Stephens, J.D. (2001) Development and Crisis of the Welfare State: Parties and Policies in Global Markets. Chicago: Chicago University Press.

Hudson, J. and Kühner, S. (2010) 'Beyond the Dependent Variable Problem: The Methodological Challenges of 
Capturing Productive and Protective Dimensions of Social Policy', Social Policy \& Society 9(2): 167-79.

Inglot, T. (2008) Welfare States in East Central Europe, 1919-2004. Cambridge: Cambridge University Press.

Jahn, D. and Kuitto, K. (2010) 'Taking Stock of Policy Performance in Central and Eastern Europe: Policy Outcomes between Policy Reform, Transitional Pressure and International Influence', European Journal of Political Research DOI: 10.1111/j.1475-6765.2010.01981.x

Jensen, C. (2008) 'Worlds of Welfare Services and Transfers', Journal of European Social Policy 18(2): 151-62.

Kangas, O. (1994) 'The Politics of Social Security: On Regressions, Qualitative Comparisons, and Cluster Analysis', in T. Janoski and A.M. Hicks (eds) The Comparative Political Economy of the Welfare State. Cambridge: Cambridge University Press.

Kangas, O. and Palme, J. (2007) 'Social Rights, Structural Needs and Social Expenditure: A Comparative Study of 18 OECD Countries 1960-2000', in J. Clasen and N.A. Siegel (eds) Investigating Welfare State Change: The 'Dependent Variable Problem' in Comparative Analysis. Cheltenham/Northampton: Edward Elgar.

Kautto, M. (2002) 'Investing in Services in West European Welfare States', Journal of European Social Policy 12(1): 53-65.

Kline, P. (1994) An Easy Guide to Factor Analysis. New York: Routledge.

Korpi, W. (2000) 'Faces of Inequality: Gender, Class, and Patterns of Inequality in Different Types of Welfare States', Social Politics 7(2): 127-91.

Korpi, W. and Palme, J. (1998) 'The Paradox of Redistribution and the Strategy of Equality: Welfare State Institutions, Inequality and Poverty in the Western Countries', American Sociological Review 63(5): 661-87.

Obinger, H. and Wagschal, U. (2001) Families of Nations and Public Policy', West European Politics 24(1): 99-14.

Organisation for Economic Co-operation and Development (2010) Social Expenditure Database (SOCX). Available at www.oecd.org/els/social/expenditure (accessed 5 October 2010).

Palier, B. (ed.) (2010) A Long Goodbye to Bismarck? The Politics of Welfare Reform in Continental Europe. Amsterdam: Amsterdam University Press.

Palme, J., Nelson, K., Sjöberg, O. and Minas, R. (2009) European Social Models, Protection and Inclusion. Institute for Futures Studies Research Report 2009/1. Stockholm: Institute for Futures Studies.
Pett, M.A., Lackey, N.R. and Sullivan, J.J. (2003) Making Sense of Factor Analysis: The Use of Factor Analysis for Instrument Development in Health Care Research. Thousand Oaks/London/New Delhi: Sage Publications.

Powell, M. and Barrientos, A. (2004) 'Welfare Regimes and the Welfare Mix', European Journal of Political Research 43(1): 83-105.

Saint-Arnaud, S. and Bernard, P. (2003) 'Convergence or Resilience? A Hierarchical Cluster Analysis of the Welfare Regimes in Advanced Countries', Current Sociology 51(5): 499-527.

Saunders, P. and Klau, F. (1985) The Role of the Public Sector: Causes and Consequences of the Growth of Government. OECD Economic Studies: Special issue 4. Paris: OECD.

Schmid, J. (2010) Wohlfahrtsstaaten im Vergleich. Soziale Sicherung in Europa: Organisation, Finanzierung, Leistungen und Probleme. Wiesbaden: VS Verlag für Sozialwissenschaften.

Serrano Pascual, A. and Magnusson, L. (eds) (2007) Reshaping Welfare States and Activation Regimes in Europe. Brussels: Peter Lang.

Siegel, N.A. (2007) 'When (Only) Money Matters: The Pros and Cons of Expenditure Analysis', in J. Clasen and N.A. Siegel (eds) Investigating Welfare State Change: The 'Dependent Variable Problem' in Comparative Analysis. Cheltenham/Northampton: Edward Elgar.

Starke, P., Obinger, H. and Castles, F.G. (2008) 'Convergence Towards Here: In What Ways, If Any, are Welfare States Becoming More Similar?', Journal of European Public Policy 15(7): 975-1000.

Szikra, D. and Tomka, B. (2009) 'Social Policy in East Central Europe: Major Trends in the Twentieth Century', in A. Cerami and P. Vanhuysse (eds) PostCommunist Welfare Pathways: Theorizing Social Policy Transformations in Central and Eastern Europe. Basingstoke: Palgrave Macmillan.

Tepe, M. and Vanhuysse, P. (2010) 'Elderly Bias, New Social Risks, and Social Spending: Investigating Change and Timing in Eight Programs Across Four Worlds of Welfare, 1980-2003', Journal of European Social Policy 20(3): 217-34.

Titmuss, R.M. (1974) 'What is Social Policy', in B. AbelSmith and K. Titmuss (eds) Social Policy: An Introduction. London: Allen and Unwin. 